\title{
RECONSTRUCTION OF MICROENVIRONMENTAL CHANGES IN THE KOPASZ HILL LOESS AREA AT TOKAJ (HUNGARY) BETWEEN 15 AND 70 ka BP
}

\author{
PÁL SÜMEGI \\ Department of Mineralogy and Geology, L. Kossuth University, 4010 Debrecen, P.O.B. 4, Hungary \\ and
}

EDE HERTELENDI

Institute of Nuclear Research, Hungarian Academy of Sciences 4001 Debrecen, P.O.B. 51, Hungary

\begin{abstract}
We collected 11 Kopasz Hill loess profiles for paleoecological and geochronological analysis. The loess accumulation and development formed during the last (Weichselian) glacial period between 70 and $15 \mathrm{ka} \mathrm{BP}$. We found that the majority of the loess profiles were composed of three typical loess strata and two well-developed paleosol horizons. Based on vertebrate remains, the lowest loess layer formed between 70-50 ka BP, during the first cool and dry climatic phase of the last glacial period, when forest steppe vegetation dominated in the Kopasz Hill area. On the surface of the lowermost layer, a paleosol developed between 50 and $40 \mathrm{ka} \mathrm{BP}$ as an indication of a more humid and warmer climatic phase. This paleosol layer was buried by a new loess layer that developed between 40 and $32 \mathrm{ka} \mathrm{BP}$. The upper paleosol horizon developed between 32 and $26 \mathrm{ka} \mathrm{BP}$. Molluscs preferring a mild climate were found in this layer, suggesting that this phase was wet and relatively temperate. A number of fired macrocharcoal remains can be found on the top of this paleosol layer. Charcoal samples from nine sites were dated by radiocarbon analyses. These results reflect the presence of a charcoal-rich horizon that developed $28-$ $26 \mathrm{ka} \mathrm{BP}$. Ca. $26 \mathrm{ka} \mathrm{BP}$, loess formation resumed. We analyzed 14 samples from 6 sites by the ${ }^{14} \mathrm{C}$ method. Based on ${ }^{14} \mathrm{C}$ data, the uppermost part of loess profiles developed between 26 and $15 \mathrm{ka}$ BP.
\end{abstract}

\section{INTRODUCTION}

The Late Pleistocene environmental history of Hungary can be regarded as one of the missing links in our understanding of the last glacial development of Europe. In terms of its location and geology, Hungary is an important area of low relief within the main mountain ranges of Central Europe (Carpathians, Alps, Dinaric Alps). As an unglaciated region during the last glacial period (Denton and Hughes 1981), Hungary may have been an important refuge for temperate fauna and flora, and one of the first regions into which refugial populations, located in the Carpathian mountains, expanded during the interstadial and interglacial periods. The most important area of the deciduous and coniferous tree relict/refugial spots (Bennett, Tzedakis and Willis 1991; Willis 1994, 1996; Willis et al. $1995,1997)$ is most likely at the border of the low mountain region and alluvial plan, where changeable micromorphological surface and different microclimatic spots could evolve.

We present here the first results of an interdisciplinary paleoecological study to reconstruct the Late Pleistocene environmental history of the northeast Hungarian loess area. The investigations were carried out on the Kopasz Hill at Tokaj. This area is the meeting point of the northern edge of the Great Hungarian Plain and the southern edge of the Hungarian low mountain (Subcarpathian) region. The techniques of sedimentological, geochemical, molluscan, macrocharcoal, radiocarbon and stable isotope analyses, with some earlier micromammalian and macromammalian results, revealed 11 loess sequences extending well into the Weichselian period (Fig. 1).

\section{STUDY AREA}

Kopasz Hill ( $515 \mathrm{~m}$ above sea level (asl), $48^{\circ} 13^{\prime} \mathrm{N}, 20^{\circ} 27^{\prime} \mathrm{E}$ ) is located in the southernmost part of the Tokaj Mountains, northeastern Hungary. Its base is made up of Sarmatian acidic pyroclastics and Sarmatian rhyolithic and perlitic extrusional masses (Gyarmati 1977). The Sarmatian volcanic surface was covered by a Lower Pannonian volcanic pyroxene dacite blanket, composed of lava flows, 
interspersed with thin volcanic slag and pyroclastics fragments (Kozák and Rózsa 1982). These eroded lava flows and lava tongues, with an area of $16.4 \mathrm{~km}^{2}$, were covered by loess $\left(12.4 \mathrm{~km}^{2}\right)$ during the Pleistocene. The loess-mantled lava flows rise $120-150 \mathrm{~m}$ above the foodplains of the Tisza and Bodrog Rivers. The lava plateaus are usually covered by a thick blanket $(10-15 \mathrm{~m}$, maximum $20 \mathrm{~m}$ ) of typical loess. Some valleys $(120-400 \mathrm{~m}$ asl) contain stone quarries where many open loess outcrops can be found on the top of the dacite rock walls. We analyzed a 11.25-m-thick loess profile (Fig. 1) at a well-known stone quarry, Patkó (Horseshoe) mine. The climate in this region today has a strong submontane character in the northern part of the hill (cooler summer: $19-20^{\circ} \mathrm{C}$ and colder winter: $-3^{\circ} \mathrm{C}$ ), and a submediterranean microclimate effect on the slopes of the southern part of the hill (warmer summer and winter: $23-24^{\circ} \mathrm{C}$ and $0^{\circ} \mathrm{C}$, respectively) (Justyák 1964).

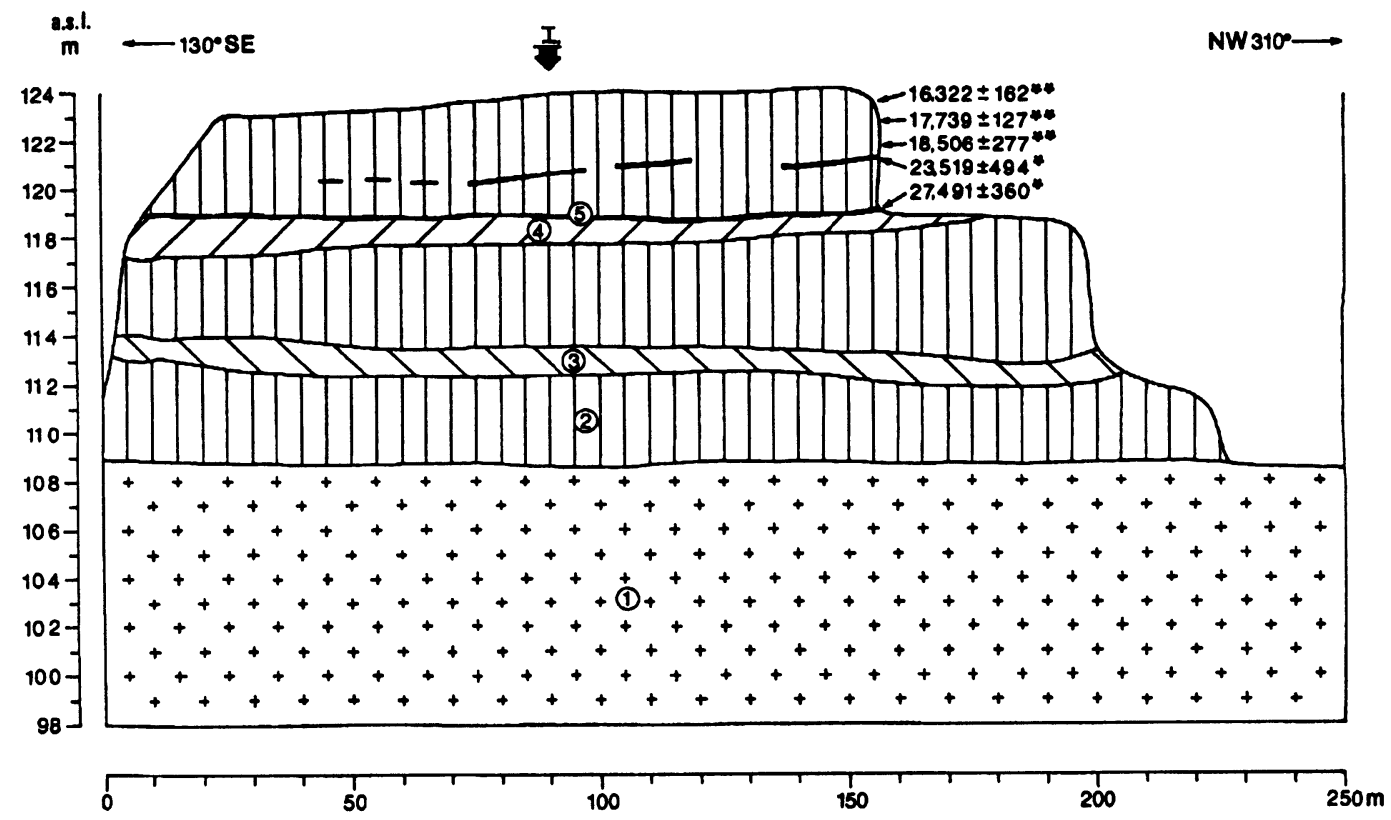

Fig. 1. The loess section of the Patkó mine at Tokaj. 1. Lower Pannonian volcanic pyroxene dacite rock. 2. Loess deposit. 3. Lower paleosol layer (ca. 50-40 ka BP). 4. Upper paleosol layer (ca. 32-26 ka BP). 5. Podzol or podzol-like paleosol horizon with high concentration of fire charcoal $(28-26 \mathrm{ka} \mathrm{BP}) .{ }^{*}={ }^{14} \mathrm{C}$ dating from charcoal. ${ }^{* *}={ }^{14} \mathrm{C}$ dating from mollusc (Arianta arbustorum) shells.

\section{METHODS}

We took 345 samples from 11 Upper Pleistocene loess sequences for sedimentological, geochemi$\mathrm{cal}$, isotope geochemical, quartermalacological and vertebrate analyses and wood anatomy (Sümegi 1996). All the loess and paleosol layers, even if they appeared homogeneous to the naked eye, were sampled in $25-\mathrm{cm}$ intervals, taking $5.3 \mathrm{~kg}\left(2 \mathrm{dm}^{3}\right)$ of sediment samples for malacological and macrocharcoal investigations and $1 \mathrm{~kg}$ samples for sedimentological and geochemical analyses. Following Sparks (1961), after drying, the sediment was disintegrated with hot water and floated on a hemispherical sieve with $0.5-\mathrm{mm}$ mesh, then all the mollusc remains and charcoal fragments and bones were sorted.

Twenty-three of the 345 samples were rich in charcoal fragments and large-body mollusc shells or vertebrate bones (Table 2). They were collected and measured with a high-precision ${ }^{14} \mathrm{C}$ dating system (Hertelendi et al. 1989). Although direct dating of mollusc remains by ${ }^{14} \mathrm{C}$ is problematical 
(Rubin and Taylor 1963; Rubin et al. 1963; Burleigh and Kerney 1982) because the results can be prone to distortion from postdepositional diagenesis or the incorporation of an unknown quantity of inorganic "dead" carbon from bedrock surface (Preece 1980, 1991; Goodfriend and Stipp 1983; Goodfriend 1987), dating shells of litter-feeder or detritus-feeder molluscs minimizes the incorporation from this possible source of old carbon, and has produced more encouraging results (Goodfriend and Stipp 1983; Preece 1991; Preece and Day 1994; Yates 1988). Thus, we used a shell-surface cleaning procedure (Hertelendi, Sümegi and Szöorr 1992) and chose the shell of a litter-feeding mollusc species, Arianta arbustorum, for dating. Some excellent results have been obtained with this species in other trials (Yates 1988; Preece 1991), suggesting that it does not incorporate significant amounts of "dead" carbon (Preece 1991).

We could estimate the age effect of the inorganic dead carbon from the bedrock surface at two locations (Szeged-Öthalom and Tokaj Csorgókút) (Table 1) where bone and shells were excavated from the same layer. The obtained rounded value $\Delta R=-200 \pm 180 \mathrm{yr}$ (Stuiver and Braziunas 1993) was added to all ${ }^{14} \mathrm{C}$ data of shells from the Arianta arbustorum. The error of the corrected ages was given according to

$$
\sigma_{\text {total }}=\sqrt{\sigma_{s}^{2}+\sigma_{R}^{2}}
$$

TABLE 1. Parallel Measurements on Bone Collagen Shells of Arianta arbustorum from the Same Layer at Szeged-Öthalom and Tokaj Csorgókút Valley Sites

\begin{tabular}{|c|c|c|c|c|c|c|c|}
\hline \multirow[b]{2}{*}{ Location } & \multicolumn{3}{|c|}{ Bone collagen $(\mathrm{P})$} & \multicolumn{3}{|c|}{ Shell (Arianta arbustorum) } & \multirow[b]{2}{*}{$\begin{array}{l}\text { Reservoir age } \\
(\Delta \mathrm{R}=\mathrm{P}-\mathrm{Q})\end{array}$} \\
\hline & Lab code & $\begin{array}{c}\text { Age } \\
\mathrm{BP} \pm 1 \sigma\end{array}$ & $\delta^{13} \mathrm{C}$ & Lab code & $\begin{array}{c}\text { Age } \\
\mathrm{BP} \pm 10\end{array}$ & $\delta^{13} \mathrm{C}$ & \\
\hline $\begin{array}{l}\text { Tokaj Csorgókút valley } \\
0.5-0.75 \mathrm{~m}\end{array}$ & Deb-2722 & $16,940 \pm 250$ & -20.24 & Deb-2656 & $17,210 \pm 160$ & -7.89 & $-270 \pm 300$ \\
\hline \multirow[t]{2}{*}{$\begin{array}{l}\text { Szeged-Öthalom }{ }^{*} \\
1.75-2.00 \mathrm{~m}\end{array}$} & Deb-3344 & $15,920 \pm 170$ & -22.31 & Deb-1483 & $16,080 \pm 150$ & -8.16 & $-160 \pm 230$ \\
\hline & & & & \multicolumn{3}{|c|}{ Weighted mean: } & $-200 \pm 180$ \\
\hline
\end{tabular}

*Large mammoth bone

We identified the lithographic features through macroscopic examination and grain size analysis (Molnár and Geiger 1995) and measured the percentage of inorganic and organic material at $25 \mathrm{~cm}$ intervals throughout the profiles by loss-on-ignition (Aaby 1986). The geochemical elements in the sediments of the Patkó mine were measured in 25-cm sections. Acid-soluble concentrations of $\mathrm{Al}$, $\mathrm{K}, \mathrm{Na}, \mathrm{Mg}, \mathrm{Ca}, \mathrm{Fe}, \mathrm{Mn}, \mathrm{Ba}$ and $\mathrm{Sr}$ were determined using ICPEAS (inductively coupled plasma emission atomic spectrometry). The macrocharcoal remains were identified by wood anatomy using the SEM (scanning electron microscope) method (Rudner 1995). We reconstructed the climate using the malacothermometer method (Hertelendi, Sümegi and Szöor 1992). Based on the ecological classification of Meier (1985), Krolopp-Sümegi (1995) and Sümegi (1996) the malacofauna was divided into the following groups: 1 . Air humidity: hygrophilous, subhygrophilous, mesophilous, and aridity-tolerant species; 2 . Temperature: cryophilous, cold-resistant, mesophilous, thermophilous elements; and 3. Vegetation: species preferring forest vegetation, species preferring open vegetation and species living in their ecotone. The malacological records also were classified according to the recent geographical distribution, following Kerney, Cameron and Jungbluth (1983) and Ložek (1964): Holarctic, Palearctic, Eurosiberian, European, SSE European, Central European, BoreoAlpin, Central-Asian mollusc elements. 
TABLE 2. Radiocarbon Data from the Loess Layers of Kopasz Hill at Tokaj

\begin{tabular}{|c|c|c|c|c|}
\hline Location & $\begin{array}{l}{ }^{14} \mathrm{C} \text { age } \\
\text { (yr BP) }\end{array}$ & $\pm 1 \sigma$ & $\begin{array}{l}\delta^{13} \mathrm{C} \\
(\% 0)\end{array}$ & Lab code \\
\hline \multicolumn{5}{|l|}{ Bodrogkeresztúr } \\
\hline Brickyard I 5.0-5.25 m* & 26,850 & 400 & -25.70 & Deb-3049 \\
\hline Brickyard I 3.25-3.5 m† & 19,800 & 150 & -8.03 & Deb-4353 \\
\hline Brickyard I 1.25-1.5 m† & 15,400 & 150 & -7.63 & Deb-4358 \\
\hline Brickyard II 3.25-3.5 m† & 17,700 & 300 & -8.55 & Deb-1614 \\
\hline Brickyard II $1.5-1.75 \mathrm{~m} \dagger$ & 14,850 & 100 & -7.82 & Deb-4340 \\
\hline \multicolumn{5}{|l|}{ Tokaj } \\
\hline Kereszt-mount I $3.75-4.0 \mathrm{~m}^{*}$ & 27,000 & 650 & -24.73 & Deb-5052 \\
\hline Kereszt-mount I $0.75-1.0 \mathrm{~m} \dagger$ & 17,600 & 150 & -8.19 & Deb-4918 \\
\hline Kereszt-mount II $4.5-4.75 \mathrm{~m}^{*}$ & 26,300 & 650 & -23.50 & Deb-2657 \\
\hline Csorgókút valley I $4.75-5.0 \mathrm{~m}^{*}$ & 26,600 & 550 & -25.42 & Deb-3042 \\
\hline Csorgókút valley I $0.5-0.75 \mathrm{~m} \ddagger$ & 16,950 & 250 & -20.24 & Deb-2722 \\
\hline Csorgókút valley I 0.5-0.75 m† & 17,200 & 150 & -7.89 & Deb-2656 \\
\hline Csorgókút valley II 5.75-6.0 m* & 28,250 & 350 & -24.88 & Deb-3035 \\
\hline Csorgókút valley II $5.0-5.1 \mathrm{~m}^{*}$ & 23,600 & 500 & -24.35 & Deb-4350 \\
\hline Csorgókút valley II 1.25-1.5 m† & 18,750 & 200 & -8.54 & Deb-4356 \\
\hline Csorgókút valley II $0.75-1.0 \mathrm{~m} \dagger$ & 17,500 & 100 & -7.75 & Deb-4330 \\
\hline Patkó-mine $5.25-5.5 \mathrm{~m}^{*}$ & 27,500 & 350 & -24.99 & Deb-3043 \\
\hline Patkó-mine $4.0-4.25 \mathrm{~m}^{*}$ & 23,500 & 500 & -24.00 & Deb-4349 \\
\hline Patkó-mine 3.0-3.25 m† & 18,500 & 300 & -7.35 & Deb-2661 \\
\hline Patkó-mine 2.5-2.75 m† & 17,750 & 150 & -10.03 & Deb-4332 \\
\hline Patkó-mine $2.0-2.25 \mathrm{~m} \dagger$ & 16,300 & 150 & -7.15 & Deb-4364 \\
\hline Railway station, $4.75-5.25 \mathrm{~m}^{*}$ & 30,200 & 1100 & -24.14 & Deb-4347 \\
\hline Tarcal, brickyard 6.75-7.0 m* & 27,250 & 300 & -24.14 & Deb-4345 \\
\hline Bodrogkeresztúr, Henye-hill $0.5-0.6 \mathrm{~m}^{*}$ & 26,300 & 350 & -25.96 & Deb-3051 \\
\hline
\end{tabular}

\section{RESULTS AND DISCUSSION}

First, results of the geological, paleontological and geochronological analyses are given for the profile of the Patkó stone quarry, then based on results of all the loess profiles. Also, maps show the paleovegetation, mean July paleotemperature, and distribution of the different environmentally adapted molluscs. The loess profile of the Patkó mine is $11.25 \mathrm{~m}$. This loess was composed of three typical strata and two well-developed paleosol horizons (Fig. 1). This unit consists of a brownishyellow, typical, unstratified loess layer with low clay content and high $\mathrm{Ca}$ and $\mathrm{Mg}$ content.

According to macrovertebrate data and some bones of Equus germanicus, Ursus spelaeus and Coelodonta antiquitatis (Pinczés 1954, 1987), the lowest loess layer was formed in the first cold phase of the Weichselian, ca. 70-60 ka BP (Kukla et al. 1988; Guiot et al. 1989; Kordos and Ringer 1991). The mollusc fauna of this loess layer contain abundant cryophilous Columella columella species. This species is indicative of a specific tundra or tundra-like environment (Ložek 1964; Rousseau 1991) and accompanying fauna do not contain any species living in milder climates (Succinea oblonga, Vallonia tenuilabris). The malacological data suggest that the mean July paleotemperature was $\mathrm{ca} .12-13^{\circ} \mathrm{C}$ when this loess layer formed. This quartermalacological horizon can be analyzed for the other loess profiles of Kopasz Hill at Tokaj. The malacological data show that the open 
(steppe-like and tundra-like) vegetation expanded and dominated on the slopes of the Kopasz Hill. It seems that the first occurrence of the Boreo-Alpin and Central-Asian cryophilous elements developed in the southern edge of the Hungarian low mountain region at this geochronological horizon parallel with the first true glacial period beginning in Europe.

On the surface of the lowermost loess layer, a dark brown paleosol with high clay content developed. A decrease in the $\mathrm{Sr} / \mathrm{Ba}$ ratio indicates that strong pedogenesis started in this phase. According to earlier results (Pécsi 1993), this paleosol level developed parallel to the Upper Mende 2 paleosol horizon, which formed ca. 50-60 ka BP. Perhaps this paleosol, within loess profiles at Tokaj, developed in the same time as the Moershoofd Interstadial (Zagwijn 1961, 1974; van der Hammen and Wijmstra 1971; Ran 1990). The decrease of $\mathrm{Ca}$ and $\mathrm{Mg}$ content in this paleosol level suggests that the carbonate content was decreased from this level during the loess weathering process (Zhong et al. 1984). Based on the traces of bioactivity, paleosol evolution formed under a temperate and humid climate. There are no mollusc remains in this layer, possibly because the shell carbonate dissolved during the soil formation process. A decrease in clay and an increase in $\mathrm{Ca}, \mathrm{Mg}$ and $\mathrm{Sr}$ content indicates a strong environmental change in the profile. This points to the end of soil formation and the beginning of a new loess formation period. Many carbonate spots are found in this middle loess layer, which may indicate a secondary washing-out processes. It is likely that mollusc shells dissolved from this layer in the course of these processes. For this reason, it is not possible to categorize this layer from a chronological and paleoecological point of view. However, on the basis of its lithostratigraphic position, it was developed during the Middle Weichselian period. Our ${ }^{14} \mathrm{C}$ data (Table 2) suggest that at ca. $32 \mathrm{ka} \mathrm{BP}$, a new environmental change began. The clay and humic content increased abruptly in the profile and the decrease in the $\mathrm{Sr} / \mathrm{Ba}$ ratio indicates the end of the loess formation period and weathering processes predominate. On top of the middle loess layer, a new reddish brown fossil soil horizon developed, with high humic and low carbonate contents. In the upper zone of this soil, a special element composition evolved, characterized by a high proportion of $\mathrm{Fe}, \mathrm{Mn}, \mathrm{P}$ and $\mathrm{Ba}$. This layer shows the highest charcoal content as well. This level seems to be a remnant of a podzol, or podzol-like soil, which was formulated not directly on the top of the middle loess layer but on a previously decarbonated fossil soil.

Based on the mollusc remains found in the fossil soil at the beginning of the Upper Weichselian (32$27 \mathrm{ka} \mathrm{BP}$ ), the climate conditions for the summer time (vegetation) on Kopasz Hill were comparable to those prevailing today. Based on malacothermometer method (Hertelendi, Sümegi and Szöôr 1992), we reconstructed a $18^{\circ} \mathrm{C}$ July mean paleotemperature on the southern slopes of the hill and $14-16^{\circ} \mathrm{C}$ July mean paleotemperature for the northern slopes. The macrocharcoal data from the high charcoal concentration level suggest that Pinus silvestris dominated on the southern part of the hill while Picea forest developed on the northern part of the analyzed region (Fig. 2). The fine-fired macrocharcoal layer and the charcoal concentration value suggest that a large wildfire or a few smaller fires occurred during this paleoecological period. A humid and mild climate induced the formation of soils, so a typical paleosol horizon, the Mende Upper Soil Complex 2 (Pécsi, Szebényi and Pevzner 1979) formed on the loess surface. Picea charcoal fragments (with a high percentage of woodland and cold-resistant species on the northern part of the hill) and Pinus silvestris remain at the same ratio with the Holarctic species (e.g., Pupilla muscorum, Vallonia costata) preferring open vegetation and mild climate, which indicates a significant difference between the two (northern and southern) parts of the hill, based on the microclimatic and microenvironmental conditions.

At the end of the period during which this upper podzol-like soil was formed, ca. 28-26 ka BP, the xerophilous snail Pupilla triplicata became absolutely dominant, indicating an extremely dry climatic condition. A charcoal maximum developed during the dry climatic period and the soil formation process stopped. 
After $26 \mathrm{ka}$ BP, the loess-dominated environment of the Kopasz Hill formed. After the wildfires between 28-26 ka BP, the distribution of the coniferous woodland decreased but survived in some small, protected ecological spots of the basin during the loess formation period. Central Asian, cryoxerophilous mollusc species, such as Vallonia tenuilabris, immigrated into the study area and were dominant on the northern part of the hill, but Columella columella, typically found in tundra or tundra-like environments (Ložek 1964; Rousseau 1991), occurred again on some parts of the region. This indicates a significant cooling and development of a cold continental steppe environment in Hungary between 25-13 ka BP. This loess layer was deposited during the cold peak of the Upper Weichselian. Although a cold and dry climate (July paleotemperature $12-15^{\circ} \mathrm{C}$ ) developed during the Upper Weichselian, two short phases (microinterstadials) could still be detected, when intermediate molluscs and some woodland elements spread from refugial areas of the Carpathians and emigrated from the Balkan peninsula to the central part of the Carpathian basin (Krolopp and Sümegi 1995). Based on ${ }^{14} \mathrm{C}$ data, the first microstadial period developed between $23-21 \mathrm{ka} \mathrm{BP}$, and the second between $18-16 \mathrm{ka}$ BP. The July mean paleotemperature increased to $15-16^{\circ} \mathrm{C}$, and a number of charcoal remains suggest that a transition from forest steppe to closed forest formed in some locations of the hill during the short time interstadials (Figs. 2 and 3). It seems that on the northern part of the hill, where there is a connection between the ancient fluvial plain and the loessy sediment, a forest refugium may have survived. Simulated experiments have demonstrated that soil temperatures in taiga forest underlain with permafrost may not increase with climate warming unless accompanied by a precipitation increase (Bonan 1992), so a mild and wet climatic phase developed during the microinterstadials and interrupted the loess formation periods. Most likely, the influence of the mild microclimate of the slopes, together with that of the wet alluvial region, made the formulation of this relict woodland patch possible during microstadials, when the mesoclimate became wetter, and more temperate forest species spread out from this refugium to other parts of the hill. In these phases, the dominance of typical boreal molluscan woodland elements such as Discus ruderatus, Vestia turgida and Semilimax kotulai increased (Krolopp and Sümegi 1990, 1991, 1995; Sümegi and Krolopp 1995) in the loess sequences, and these woodland elements began spreading on the hill (Fig. 3).

It seems that the Upper Weichselian environment was mosaic-like on the hill. The various plants and animals could spread from different ecological spots during times of climate change when the distribution of the forest or grass, or their ecotone, or perhaps the tundra-like habitat extended. The paleoecological and ${ }^{14} \mathrm{C}$ data confirm that the northern part of the hill supported a relictual forest spot with a local mobile zone, which developed around the forest area. On this oscillation zone, the different ecological habitat favoring animals or plants could occur and spread from their relict areas, or quickly draw back to the relict areas during times of climatic and environmental change in the Upper Weichselian.

When the loess formation ended in the Carpathian basin, a new ecological stage developed. Based on ${ }^{14} \mathrm{C}$ data, the loess formation ended $c a .12 \mathrm{ka}$ BP when the climate became progressively warmer and cryophilous elements became extinct in the Carpathian basin (e.g., Vallonia tenuilabris), or some of them drew back from the inner part of the Carpathian basin (Pannonicum) to the Carpathians (e.g., Columella columella). This loess layer, however, was not found on the hill. The youngest loess layer was probably eroded by human activities. The first productive human communities settled between 6-7 ka BP in the region. Based on the ${ }^{14} \mathrm{C}$ data for this period, the first strong evidence of human activity, including clearance burning and soil erosion, can be detected throughout the entire northern part of Hungary (Willis et al. 1995). It seems that the vegetation degradation and soil erosion started when Neolithic farming communities began to settle in the Carpathian basin. The influences of this process became stronger and continues today because of intensive use of agriculture (Boros 1977). 

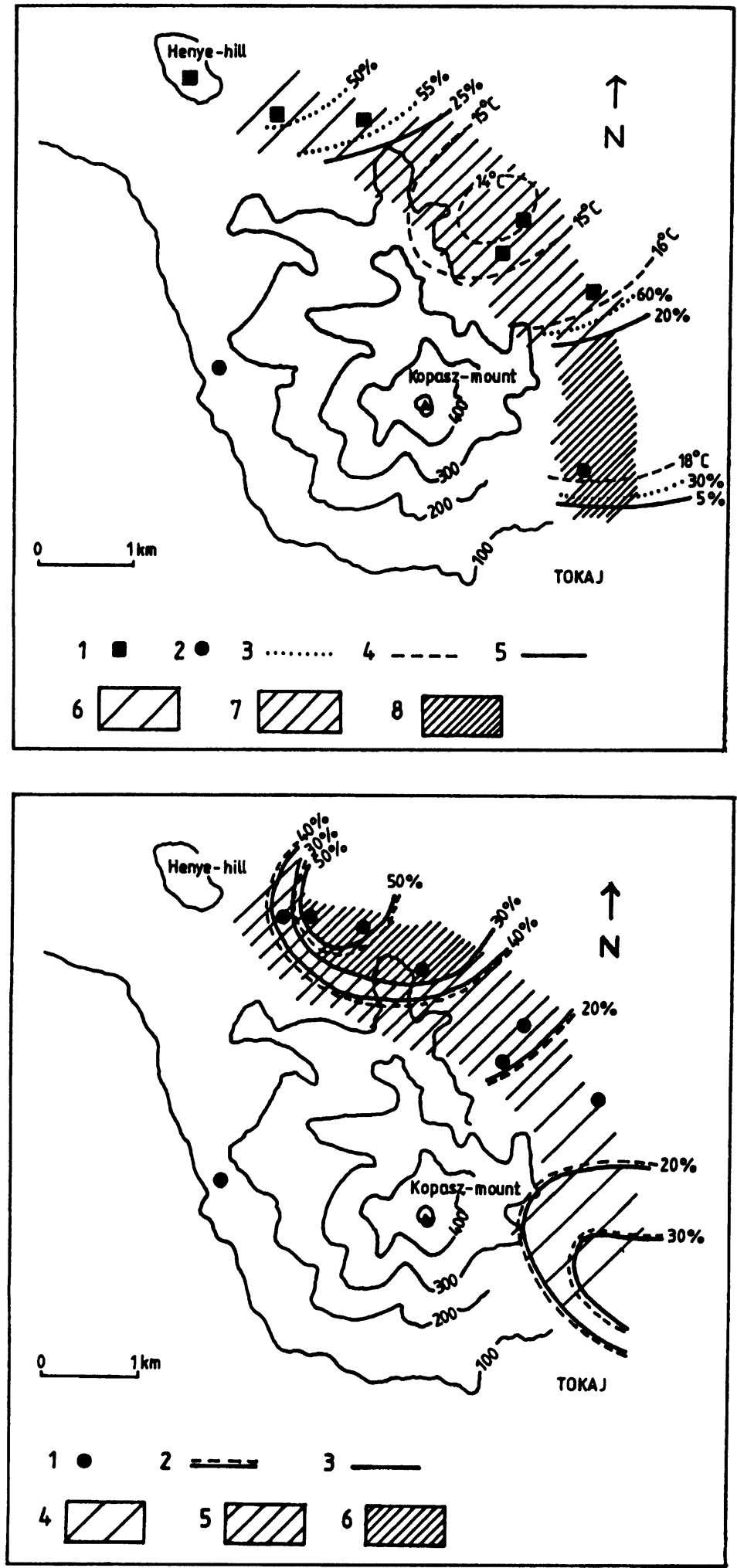

Fig. 2. Reconstructed paleoecological stage for Kopasz Hill at Tokaj 28-26 ka BP. 1. Picea charcoal site. 2. Pinus silvestris charcoal site. 3. Percentage of open vegetation habitat favoring mollusc dominance. 4. Mean July paleotemperature. 5. Percentage of the woodland habitat favoring mollusc dominance. $6 .<50 \%$ of the Holarctic mollusc elements. 7. Percentage of the Holarctic species dominance is between 50 $60 \%$. 8. $>60 \%$ of the Holarctic species dominance.

Fig. 3. Reconstructed paleoecological stage on Kopasz Hill at Tokaj 18-16 ka BP. 1. The Carpathians, closed forest habitat favoring Vestia turgida (mollusc) sites. 2. Percentage of the ecotone habitat favoring molluscs. 3. Percentage of the woodland habitat favoring mollusc dominance. 4 . $<20 \%$ of the woodland habitat favoring Central European mollusc dominance. 5. $20-30 \%$ of the woodland habitat favoring Central European mollusc dominance. 6 . $>30 \%$ of the woodland habitat favoring Central European mollusc dominance. 


\section{CONCLUSION}

The loess sequences from Kopasz Hill at Tokaj provide an important record of the environmental changes in northern Hungary from the first real cold phase of the last glacial period to the end of the Weichselian. During the last glacial period, cyclic, climatic and environment changes occurred in the analyzed region and three cooler stadial and two temperate interstadial climatic phases can be recorded by geological, paleontological and chronological methods.

The paleovegetation and quartermalacological data suggest that the forest flora and fauna did not become extinct during the loess formation time, but a relict forest spot is identified on the one of the slopes of the northern part of the hill. There was a borderline of loess sediment and as well as an ancient floodplain sediment. From this region, the forest elements expanded at times, which indicates some strong climatic and environmental changes during the last glacial period. ${ }^{14} \mathrm{C}$ and paleoecological data confirm that a local oscillation zone developed around this forest spot. Here, open woodlands, or their ecotone habitat-preferring animals, could live and spread out from their relict areas, or draw back to the areas during short (1-2 ka) climatic and environmental changes. It seems that the Weichselian environment of the Kopasz Hill was mosaic-like, where the "cold-stage" or open vegetation-preferring taxa, and the "warm stage" or woodland-preferring taxa could live near each other (double refugial effect).

\section{REFERENCES}

Aaby, B. 1986 Palaeoecological studies of mires. In Berglund, B. E., ed., Handbook of Holocene Palaeoecology and Palaeohydrology. New York, John Wiley \& Sons: 111-126.

Bennett, K. D., Tzedakis, P. C. and Willis, K. J. 1991 Quaternary refugia of Northern European trees. Journal of Biogeography 18: 103-115.

Boros, L. (ms.) 1977 Erosion of the loess blanket of Nagy Hill at Tokaj. Ph.D. dissertation. Debrecen, Hungary (in Hungarian).

Bonan, G. B. 1992 Soil temperature as an ecological factor in boreal forests. In Shugart, H. H., Leemans, R. and Bonan, G. B., eds., A Systems Analysis of the Global Boreal Forest. London, Cambridge University Press: 126-144.

Burleigh, R. and Kerney, M. P. 1982 Some chronological implications of a fossil molluscan assemblage from a Neolithic site at Brook, Kent, England. Journal of Archeological Science 9: 29-38.

Denton, G. H. and Hughes, T. J. 1981 The Last Great Ice Sheets. New York, John Wiley \& Sons: 488 p.

Goodfriend, G. A. 1987 Radiocarbon age anomalies in shell carbonate of land snails from semi-arid areas. Radiocarbon 29(2): 159-167.

Goodfriend, G. A. and Stipp, J. J. 1983 Limestone and the problem of radiocarbon dating of land-snail shell carbonate. Geology 11: 575-577.

Guiot, J., Poas, A., de Beaulieu, J. L. and Reille, M. 1989 A 140,000-year continental climate reconstruction from two European pollen record. Nature 338: 309 313.

Gyarmati, P. 1977 The Tokaj Mountains. Budapest,

MÁFI Évkőnyve: 136 p. (in Hungarian).

Hertelendi, E., Csongor, E., Záborszky, L., Molnár, J., Gál, J., Györffy, M. and Nagy, S. 1989 A counter system for high-precision ${ }^{14} \mathrm{C}$ dating. In Long, $\mathrm{A}$., $\mathrm{Kra}, \mathrm{R}$. S. and Srdoc, D., eds., Proceedings of the 13 th International ${ }^{14} \mathrm{C}$ Conference. Radiocarbon 31(3): 399406.

Hertelendi, E., Sümegi, P. and Szöör, Gy. 1992 Geochronologic and paleoclimatic characterization of Quaternary sediments in the Great Hungarian Plain. In Long, A. and Kra, R. S., eds., Proceedings of the 14th International ${ }^{14} \mathrm{C}$ Conference. Radiocarbon 34(3): 833839.

Justyák, J. 1964 Fieldclimate measurings on the southern slope of the Kopasz hill at Tokaj. Acta Geographica, Geologica et Meteorologica Debrecina 10: 27-38 (in Hungarian).

Kerney, M. P., Cameron, R. A. D. and Jungbluth, J. H. 1983 Die Landschnecken Nord-und Mitteleuropas. Hamburg, Parey: 384 p.

Kordos, L. and Ringer, Á. 1991 Climatostratigraphic and archeostratigraphic correlation of Arvicolidae stratigraphy of the Late Pleistocene in Hungary. MÁFI Évi Jelentése 1989 Evról: 523-533.

Kozák, M. and Rózsa, P. 1982 The geological evolution history and morphological outlines of Tokaj-Nagyhegy. Acta Geographica Debrecina 20: 167-190 (in Hungarian with English summary).

Krolopp, E. and Sümegi, P. 1990 Vorkommen von Vestia turgida (Rossmässler 1836) in den pleistozänen Sedimenten Ungarns. Soosiana 18: 5-10.

1991 Dominancia level of the species Punctum pyg- 
maeum (Draparnaud, 1801): A biostratigraphical and paleoecological key level for the Hungarian loess sediments of the Upper Würm. Soosiana 19: 17-23.

1995 Palaeoecological reconstruction of the Late Pleistocene, based on Loess Malacofauna in Hungary. GeaJournal 36: 213-222.

Kukla, G. J., Heller, F., Liu, X. M., Yu, T. C., Liu, T. S. and $A$, Z. S. 1988 Pleistocene climates in China dated by magnetic susceptibility. Geology 16: 811-814.

Ložek, V. 1964 Quartärmollusken der Tschechoslowakei. Rozpravy Ústredniho Ústavu Geologického 31: 374.

Meier, T. 1985 The pre Weichselian nonmarine molluscan fauna from Maastricht-Belvedére (Southern Limburg, the Netherlands). Mededelingen Rijks Geologische Dienst 39: 75-103.

Molnár, B. and Geiger, J. 1995 Possibility for subdividing apparently homogeneous depositional sequences by combined use of sedimentological, palaeontological and mathematical method. GeaJournal 36: 169-177.

Pécsi, M. 1993 Quaternary and Loess Research. Budapest, Akadémiai: 375 p. (in Hungarian with English summary).

Pécsi, M., Szebényi, E. and Pevzner, M. A. 1979 Upper Pleistocene Litho- and Chrono-stratigraphical type profile from the exposure at Mende. Acta Geologica Hungarica 22: 371-389.

Pinczés, Z. 1954 The loess blanket of Nagy-hegy at Tokaj. Földrajzi Ertesito 3: 575-584 (in Hungarian).

1987 Guide Book of Excursions. Debrecen, Carpatho-Balcan Geomorphological Commission: 64 p.

Preece, R. C. 1980 The biostratigraphy and dating of the tufa deposit at the Mesolithic site at Blashenwell, Dorset, England. Journal of Archeological Science 7: 345-362.

1991 Accelerator and radiometric radiocarbon dates on a range of materials from colluvial deposits at Holywell Coombe, Folkstone. In Lowe, J. J., ed., Radiocarbon Dating: Recent Applications and Future Potential. Quaternary Proceedings 1: 45-53.

Preece, R. C. and Day, S. P. 1994 Comparison of Postglacial molluscan and vegetational succession from a radiocarbon dated tufa sequence in Oxfordshire. Journal of Biogeography 21: 463-478.

Ran, E. T. H. 1990 Dynamics of vegetation and environment during the Middle Pleniglacial in the Dinkley Valley (the Netherlands). Mededelingen Rijks Geologische Dienst 44: 141-208.

Rousseau, D. D. 1991 Climatic transfer function from Quaternary molluscs in European loess deposits. Quaternary Research 36: 195-209.

Rubin, M., Likins, R. S. and Berry, E. G. 1963 On the validity of radiocarbon dates from snail shells. Journal of Geology 71: 84-89.

Rubin, M. and Taylor, D. W. 1963 Radiocarbon activity of shells from living clams and snails. Science 141: 637.
Rudner, E. (ms.) 1995 Reconstruction of the Upper Pleistocene vegetation of Hungary based on wood anatomy. M.S. dissertation, Debrecen: 57 p. (in Hungarian).

Sparks, B. W. 1961 The ecological interpretation of Quaternary non-marine Mollusca. Proceedings of the Linnean Society of London 172: 71-80.

Stuiver, M. and Braziunas, T. F. 1993 Modeling atmospheric ${ }^{14} \mathrm{C}$ influences and ${ }^{14} \mathrm{C}$ ages of marine samples to 10,000 BC. In Stuiver, M., Long, A. and Kra, R. S., eds., Calibration 1993. Radiocarbon 35(1): 137-189.

Sümegi, P. (ms.) 1996 Comparative paleoecological and stratigraphical valuation of the NE Hungarian loessareas. Ph.D. thesis, Kossuth University, Debrecen: 120 p. (in Hungarian).

Sümegi, P. and Krolopp, E. 1995 Reconstruction of paleoecological condition during the deposition of Würm loess formation of Hungary based on malacological investigations. Földtani Közlöny 124: 125-148 (in Hungarian with English abstract).

van der Hammen, T. and Wijmstra, T. A., eds., 1971 The Upper Quaternary of the Dinkley valley (Twente, Eastern Overijssel, The Netherlands). Mededelingen Rijks Geologische Dienst 22: 55-214.

Willis, K. J. 1994 The vegetation history of the Balkans. Quaternary Sciences Reviews 13: 769-788.

1996 Where did all the flowers go? The fate of temperate European flora during glacial periods. Endeavour 20: 110-114.

Willis, K. J., Sümegi, P., Braun, M. and Tóth, A. 1995 The Late Quaternary Environmental History of Bátorliget, N.E. Hungary. Palaeoclimatology, Palaeoecology, Palaeogeography 118: 25-47.

1997 Does soil change cause vegetation change or vice versa? A temporal perspective from Hungary. Ecology 78: 740-750.

Yates, T. J. S. 1988 The detection of diagenetic change in non-marine shells prior to their submission for ${ }^{14} \mathrm{C}$ dating. In Olsen, S. L., ed., Scanning Electron Microscopy in Archaeology. BAR International Series 452. Oxford, British Archaeological Reports: 239-248.

Zagwijn, W. H. 1961 Vegetation, climate and radiocarbon datings in the Late Pleistocene of the Netherlands. Part I: Eemian and Early Weichselian. Mededelingen Rijks Geologische Dienst 14: 15-45.

1974 Vegetation, climate and radiocarbon datings in the Late Pleistocene of the Netherlands. Part II: Middle Weichselian. Mededelingen Rijks Geologische Dienst 25: 101-111.

Zhong, W. Q., Yang, W. H., Diago, G. Y., Sun, F. Q., Yu, S. H. and Liu, Y.M. 1984 The evolution of chemical elements in loess of China and paleoclimatic conditions during loess deposition. In Pécsi, M., ed., Lithology and Stratigraphy of Loess and Paleosols. Budapest, Geography Research Institute, Hungarian Academy of Sciences: 161-170. 